KOMMUNIKÁCIÓ,

KÖZVÉLEMÉNY, MÉDIA

2014/3. szám

A tartalomhoz $>>$

\title{
Hegyi Ádám
}

\section{"...A BÉ KÜLDÖTT INFORMATIONAK VÉLÜNK VALÓ NEM KÖZLÉSE..."}

\section{INFORMÁCIÓK AKADÁLYOZÁSA ÉS TERJESZTÉSE A BÉKÉSI REFORMÁTUS EGYHÁZMEGYÉBEN A 18-19. SZÁZAD FORDULÓJÁN[1]}

A reformáció során Európában a protestáns egyházak különböző egyházigazgatási struktúrákat hoztak létre. A református egyház kormányzati rendszere Magyarországon nem teljesen követte a kálvini elveket, mert a 16. században Kálvin presbiteri egyházkormányzatot vezetett be, nálunk viszont az esperesi és superintendensi hivatal bevezetésével alá-fölérendeltségi viszonyt teremtettek, és a világi elemek egyházkormányzatba való bevonását ellenezték. Az alulról építkező egyház legfőbb intézménye nálunk is a gyülekezet lett, de történeti okokból az egyházközségek önállóságát az egyházmegyék és az egyházkerületek korlátozták. Természetesen ez a korlátozás össze sem hasonlítható a katolikus egyház centralizált egyházszervezetével. A 17. századtól kezdve a puritán és a presbiteriánus mozgalom képviselte a világiak egyházkormányzatba való bevonását, de a földesurak ellenezték a jobbágyok egyházkormányzati szerepvállalását. A 18. században, de főleg a Carolina Resolutio életbe lépése után megerősödött a világiak befolyása az egyházban, mert a református egyház csak gazdag nemesek támogatásával tudta érdekeit érvényesíteni. Így jött létre az ágensi hivatal és rendszeressé váltak a konventek, mert zsinatot hivatalosan nem lehetet összehívni. A konvent eredetileg nemesi birtokon tartott világiak megbeszélése volt, ahol az egyház megsegítéséröl tanácskoztak, de egy idő után vezető egyházkormányzati szervvé vált. 1791-ben Sinai Miklós püspökké választásával kiéleződött a világiak és egyháziak közötti érdekellentét. A vita során alulmaradtak a tisztán egyházi vezetést támogatók (hyerarchikusok) a világiak térnyerésével 
szemben (kyriarchikusok), és a 19. század elejére a kálvinista egyházigazgatás teljes egészében laikusok és lelkészek közös kormányzati (presbiteri) rendszerévé alakult át, miközben megmaradt a hierarchikus kormányzati rendszer. Az 1791-ben létrehozott igazgatási struktúra egészen 1881-ig érvényben maradt a királyi Magyarország területén (Molnár Ambrus 1995).

Tanulmányomban a református egyházigazgatás egyik középszintű intézményét, a Békési Református Egyházmegyét fogom részletesen bemutatni. Vizsgált időszakom 1791-1821 közötti évekre esik, mert a budai zsinat (1791) és a pesti konvent (1821) között eltelt időszak kimondottan érdekes az egyházkormányzat szempontjából, mivel ekkora szilárdult meg a világiak egyházkormányzati szerepe. De mielőtt rátérnék az elemzésre, néhány szót érdemes szólni a hazai református egyház kora újkori kormányzati rendszerében zajló információáramlásról. Mivel a kálvinista egyházszervezet alapvető kritériuma a gyülekezetben gyakorolt vallásosság, ezért az egyház struktúrája a hierarchikus rendszer ellenére csak enyhén volt centralizált. Az egyházkerületek éléről a superintendens az egyházmegyék vezetőinek, az espereseknek adott általában utasításokat, és az esperesek továbbították azokat az egyházközségek élén álló lelkészek számára. Az információ hivatalos útja, tehát többlépcsős volt, miközben az informális kommunikációs hálózatok egészen más alakzatokat vettek föl. Jó példa erre, hogy a lelkészek közvetlen kapcsolatot is ápoltak az egyházkerülettel. Szervezetszociológiai szempontból ez a rendszer nem volt hatékony, de mégsem omlott össze, mert sem az 1715. évi XXXI. törvény hatására, sem a Carolina Resolutio hatására nem semmisült meg (Szabó Zoltán József 2004: 79-82).

\section{A tanulmány módszertana}

Az információtörténet historiográfiája bővelkedik olyan vitákkal, amelyek arról szólnak, mennyire lehet önálló történeti kutatásként az információ történetével, hatástörténetével foglalkozni (Karvalics László, Z. 2012; Weller, Toni 2008; Weller, Toni 2012). Tény és való, hogy a könyvtártörténet, a cenzúra története vagy a média története mai közvélemény szerint sok ponton kapcsolódik az információs társadalom kialakulásának történetével. Miközben egyre több olyan monográfia jelenik meg, amelyik egy-egy történelmi eseményt a résztvevők tudásának rekonstruálásával próbálnak meg bemutatni. Így például megvizsgálták, hogy a kaliforniai aranyláz idején milyen információkra tettek szert az aranyásók és honnan szerezték azokat (Stillson, Richard T. 2008). A hazai kutatók közül csak példaként említem Szommer Gábor (2004) és Novák Veronika (2007) munkáit, amelyek szintén az információ útjának rekonstruálásával foglalkoztak. Úgy gondolom az információtörténet esetében, nem lehet éles határt vonni az egyes történeti diszciplínák között, hiszen például a közigazgatás története egyben a kommunikációs hálózatok és az információáramlás történetével is foglalkozik. A következőkben nem a Békési Református 
Egyházmegye müködését kívánom rekonstruálni, hanem azt, hogy bizonyos információk elhallgatása/terjesztése hogyan volt lehetséges az esperességben. Munkám ennek megfelelöen egyszerre információtörténeti, egyháztörténeti, igazgatástörténeti és müvelödéstörténeti tanulmány.

1787-ben a hódmezővásárhelyi református egyházat az egyházkerület felelősségre vonta, mert bizonyos információkat elhallgatott a superintendens előtt. A kialakult vitában, egymást kölcsönös félretájékoztatással vádolták meg:

"Az a levél, az az ujabb nem felelés, vagy a bé küldött informationak vélünk való nem közlése jele, hogy nem biznak igazságokhoz a bé küldött informationak helyes vóltához, hogy az ollyan vólna, a melly azok előtt is a kik a dolgot jobban tudják és közelebbről mehetnének végére mindennek meg állhasson. Mert ha biznának miért nem mertek hát felelni? Miért nem merték a bé küldött informatiot vélünk közölni. De ha nevezetesen a bé küldött informatióhoz nem biznak, ugy csalni akarják Fő Tiszt. Super. Urunkat és V. Super. a melly felettébb való."[2]

A Türelmi Rendelet, majd az 1791. évi 26. törvény értelmében az evangélikus és a református egyházak helyzete jelentősen javult, mert annak hatására az egyházigazgatás megszabadult a katolikus ellenőrzéstől: az egyházkormányzásba a régi nagy ellenfél nem szólhatott bele, a protestánsok a szentségek kiszolgálásában és az egyházlátogatásban szabad kezet kaptak. Sőt! 1781. után a gyülekezetek iratkezelését sem ellenőrizhette a katolikus egyház. Ennek következtében az egyházigazgatás új erőre kapott, mert a 18. század utolsó két évtizedéből jóval nagyobb arányban maradtak ránk források, mint az 1781et megelőző időszakból. (Bucsay Mihály 1985: 177-180.; Zoványi Jenő II. 2004: 109-130.; Körmendy Lajos 2009: 266.)

A Békési Református Egyházmegyében elhallgatott, vagy nyilvánosságra hozott információkat a következőképpen vizsgáltam meg: először az egyházmegye fennmaradt teljes iratanyagát átnéztem, majd ezt követően kiválasztottam azokat az ügyeket, amelyek során az irat készítője információhiányra hívta fel a figyelmet, illetve az irat készítője minél nagyobb közönség számára kívánta közzétenni a dokumentum tartalmát. Azokat az eseteket, amikor a forrás lejegyzője számára nem derült ki, hogy valamilyen adatot elhallgattak előtte, nem vontam be a vizsgálatba, mert a releváns kép érdekében azok a titkolózások/nyilvánosságra hozások fontosak számunkra, amelyek a vizsgált időszakban az egyházmegye vezetői előtt ismertté váltak. Így tehát azok a dokumentumok érdekesek számunkra, amelyekben utasítások találhatóak annak információjával kapcsolatban.

Annak érdekében, hogy az elemzés hiteles legyen meg kell ismernünk az egyházmegye korabeli irattári rendszerét és igazgatási struktúráját. Ezt követően két kategóriára bontva (nyilvános-, és titkos információk) be fogom mutatni a megtalált forrásokat. Az iratok áttekintése után nyílik arra lehetöségünk, hogy eldöntsük, az elhallgatás vagy nyilvánosságra való hozás milyen módszerrel történt: az egyházmegye hivatalos csatornáin 
keresztül, vagy informális úton. Ezzel párhuzamosan azt is meg lehet mondani, hogy a titkolózás/nyilvánosságra hozás mennyire volt sikeres.

\section{I ratkezelés és egyházigazgatás a békési egyházmegyében}

A vizsgált időszakban a Békési Református Egyházmegye több vármegye reformátusait fogta össze a Körösök völgyeitől egészen a Bánátig. A traktus azért lett ilyen nagy terjedelmü, mert a 19. század elején egyre több kálvinista telepes falu jött létre a Délvidéken, amelyekhez a legközelebbi református egyházmegye a Békési volt (Kis Bálint 1992: 79-81.). A nagy földrajzi távolságok megnehezítették az egyházmegye kormányzását, amelyet leginkább a vizitációs jegyzőkönyvek és az egyházmegyei gyülések résztvevőinek névsora mutat. A Bánátban található településeken (Rittberg, Liebling, Torontálvásárhely, Franzfeld, Magyarittebe, stb.) az esperes soha sem jelent meg személyesen, hanem a vizitációt valamelyik Temes vármegyei szolgabíró és egy gyülekezeti lelkész, esetleg assessor végezte el. (Barcsa János II. 1908: 122.)[3] Ehhez hasonlóan egyházmegyei gyüléseket sosem tartottak a Bánátban és az ott élő lelkészek alig-alig jelentek meg személyesen az egyházmegye vezetése előtt (TtREL I.29.a.2). Ráadásul Torontálvásárhely katonai határőrvidéken volt található, ahol a katonai igazgatás gyakran egyházi ügyekbe is beleszólt (Barcsa János II. 1908: 84).

Tudjuk, hogy a hazai református egyház története során az esperesi hivatal úgynevezett mozgó hivatalként jött létre, amely azt jelentette, hogy a traktus vezetőjének nem volt állandó székhelye, hanem mindig arra a településre szállították át az egyházmegye levéltárát, ahol az esperes lelkipásztorként szolgált (Molnár Ambrus 1995). Ez azon kívül, hogy igen sérülékennyé tette a levéltár tartalmát, azt is jelentette, hogy nagyon nagy iratanyag nem keletkezhetett az évszázadok során, hiszen azt nehéz lett volna szállítani. Vizsgált korszakunkhoz viszonylag közel, 1762-ben szabályozták részletesen az egyházmegyék iratkezelési gyakorlatát. Ebben elöírták, hogy a traktus gyüléseiröl jegyzőkönyvet kell vezetni és az egyházlátogatások során feltett kérdéseket szintén külön protokollumba kellett vezetni (Tóth Endre 1964: 68). Az 1791. évi budai zsinat 9. kánonja szintén előírta a jegyzőkönyvek vezetését, és külön felhívta az esperesek figyelmét arra, hogy az egyházmegyei levéltárban irattári rendet kell kialakítaniuk (Révész Kálmán 1860: 58-62.). Az esperesek évente kötelesek voltak az egyházkerület számára írásos beszámolót készíteni az egyházmegyében történtekről, de ezek elkészítését gyakran szabotálták (Barcsa János II. 1908: 122). Szintén a budai zsinat kánonjaiban szerepelt, hogy az egyházmegyék kötelesek az egyházkerület utasításait végrehajtani, amely azt jelentette, hogy a superintendenstől, főjegyzőtől vagy a főgondnoktól rendszeresen kaptak körrendeleteket (Révész Kálmán 1860: 58-62.). A vezetői feladatok megkövetelték egyéb írásos dokumentumok készítését is, így például az esperes körleveleket intézett a lelkészekhez, a 
napi ügyekről úgynevezett esperesi naplót vezetett, a gyülekezetek vezetői leveleztek az esperessel, a vitás ügyekről beadványokat, jelentéseket, panaszokat készített (Molnár Ambrus 1989).

A Békési Református Egyházmegye levéltárát a 19. század végén Szeremley Sámuel rendezte, de az általa kialakított levéltári rend mára felborult, mert a Tiszántúli Egyházkerület Levéltárának fondrendszerébe olvasztották be.[4] Saját tapasztalatom alapján ki merem jelenteni, hogy 1791-1821 között az egyházmegye esperesei semmilyen irattári rendet nem alakítottak ki, egyedül a jegyzőkönyvekben szereplő ügyeket számozták, de a hozzájuk tartozó iratokat nem látták el irattári jelzettel. Az irattári rend hiányát mutatja az is, hogy 1812-ben sikertelenül próbálkoztak meg a dokumentumok rendezésével.[5] Az egyházmegyei gyüléseken, az egyházmegyei vizitációkon, esperesi naplókon és esperesi jelentéseken kívül más rendszeresen vezetett dokumentum nem készült a békési traktusban.

Szerencsére ma is megtalálhatóak az egyházmegye közgyülésének jegyzőkönyvei (TtREL I.29.a.2.) és az egyházlátogatások protokollumai (TtREL I.29.h.1.), az esperesi naplót viszont csak 1816-tól kezdték el vezetni (TtREL I.29.o.1.). A források tanúsága szerint az egyházlátogatások során vizsgálták meg a gyülekezetekben előforduló panaszokat, és az egyházmegyei gyülés tárgyalta azokat, ha nem sikerült helyben elintézni őket. A vizitáció során készült beadványok, panaszok többnyire elkallódtak, mára már csak a jegyzőkönyvi bejegyzések tudósítanak a nézeteltérésekről.[6] Rajtuk kívül felsőbbhatósági körlevelek (TtREL I.29.f.3.) és az esperes által külön kezelt iratok maradtak fönn (TtREL I.29.c.). A felsőbbhatósági körlevelek az egyházkerület, a helytartótanács és a vármegyék szerveitől kerültek ki, míg az esperes által kezelt iratok között, igen heterogén iratokat találunk: lelkészek elleni panaszokat, feljelentéseket, esperesi körleveleket, gyülekezeti tagok vétkeit összefoglaló jelentéseket, stb. Az esperesek által az egyházkerület számára készített jelentések megtalálása szinte lehetetlen, mert mintegy 50 dobozban szétszórva helyezték el ezeket (TtREL I.1.b.16-67.).

Az átnézett iratokból az derült ki, hogy az egyházmegyében terjedő vagy nem terjedő információk útja alapvetően az egyházmegyei közgyủlés jegyzőkönyvéből követhető nyomon, de értékes adatok kerültek elő az esperes által külön kezelt iratokban is.

Mivel az egyházmegye kommunikációs hálózatát a református egyház törvényei szabályozták, meg kell néznünk, hogyan épült fel a hivatalos struktúra, és hogyan müködött az informális rendszer.

Az egyházmegye szervezetét különböző egyházi törvények írták elö. Vizsgált korszakunkban a budai zsinat kánonjai voltak az iránymutató rendelkezések, annak ellenére, hogy a királyi szentesítés elmaradása miatt, ezek soha sem léptek hatályba. A gyakorlat viszont azt mutatja, hogy hatásuk egyértelmüen kimutatható, mert ekkortól kezdve terjedt el széles körben a presbiteri kormányzási rendszer az egyházban (Révész Kálmán 1891). A 
budai zsinat kánonjain kívül a Tiszántúli Egyházkerületben a Gelji-féle kánonokat, a Zoványi-féle kánonokat és az 1762-es egyházlátogatási határozatokat is használták. A budai zsinat határozataihoz képest ezek a világiak egyházkormányzati szerepét igyekeztek háttérbe szorítani, de az egyházmegyét érintő területeken sok egyezést mutatnak. Ezek alapján kijelenthetjük, hogy az egyházmegye vezetője az esperes és a világi gondnok volt. Az esperes, a gondnok és az assessorok (tanácsbírák) együtt alkották a traktus döntéshozó testületét, a konzisztóriumot. A tanácsbírákat világiak és egyháziak közül egyenlő arányban választották. Kivételes esetekben egyházkerületi engedéllyel a konzisztórium tagja lehetett az egyházközség küldötte is, és egy küldött ilyenkor több egyházat is képviselhetett. Az egyházmegyei konzisztórium elnöke az esperes és a gondnok volt. Hitéleti kérdésben az esperes, más ügyekben a gondnok szavazata döntött (Tóth Endre 1964: 4-5; Barcsa János II. 1908: 47; Szentpéteri Kun Béla 1948: 80.).

A békési egyházmegyében általában évente kétszer hívták össze a konzisztóriumot, és az ülések közti időben az esperes intézte a napi ügyeket. Az egyházlátogatást rendszeresen gyakorolták, amelynek alkalmával lehetőség nyílt egyházkormányzati ügyek elintézésére is. Vizsgált korszakunkban az esperesi tisztséget folyamatosan betöltötték, míg a világi gondnok rendszeres müködéséről 1795-től kezdve vannak adataink. A tanácsbírók száma általában 5-7 fő között mozgott, akik közül felváltva találunk világiakat és egyháziakat is. Arra viszont nem volt példa, hogy lelkész, vagy gyülekezeti tag a konzisztóriumon szavazati jogot kapott volna (TtREL I.29.a.2.). Ezek alapján kijelenthetjük, hogy az egyházmegye hivatalos ügyviteli rendszere az egyházlátogatáson és az egyházmegyei gyülésen keresztül zajlott. A nem hivatalos ügymenet a gyülekezetek között és bizonyos esetekben a gyülekezetek és az esperes között volt megfigyelhető. Ilyennek számított, amikor az esperes jóváhagyása nélkül döntöttek egyházmegyei ügyben, esetleg konzisztóriumi döntést kívántak téves információkkal befolyásolni: feljegyzéseket tartottak vissza, nem jelentek meg az esperes színe előtt, stb.

Miután áttekintettük a traktus iratkezelési szokásait és szervezeti felépítését, nézzük meg, milyen források kerültek elő, amelyek információ visszatartásával, vagy terjesztésével kapcsolatosak. Először azokat nézzük meg, amelyek célja az volt, hogy minél több emberhez eljussanak a bennük rejlő adatok.

\section{Nyilvános információk}

Az írott információ alapvetően kézzel írott dokumentumokban terjedt a Dél-Alföldön, mert a helybeli nyomdák kis száma, nem tette lehetővé gyorsan sokszorosítható iratok terjesztését. A Békési Református Egyházmegye területén a vizsgált korszakban nem müködött nyomda, hozzá legközelebb Szegeden 1801-ben és Aradon 1819-ben alapítottak nyomdát (Szabó Ferenc 2008:112. Gaál Endre 2001.), miközben a nyomdatermékek iránt 
egész nagy érdeklődés volt megfigyelhető: a reformáció 300 éves évfordulójára megjelent ünnepi kiadvány előfizetői és támogatói között többen is Békésről, Hódmezővásárhelyről, Gyuláról, Gyomáról rendelték meg a kötetet (Glatz Jakob - Márton József 1818).

A fennmaradt források arról tanúskodnak, hogy az egyházmegye számára fontos nyilvános információk terjedését igyekeztek minél hatékonyabban és gyorsabban megoldani. Így például II. Lipót halála alkalmából tartandó Istentiszteleteket fontos volt minél előbb minden gyülekezetben megszervezni, mert az uralkodóházhoz való hüség bizonyításával igyekezett a református egyház a kivívott szabadságát megtartani. Nem meglepő, hogy Hunyadi Ferenc püspök saját kezével írt levelet Szőnyi Benjámin esperesnek, amelyben utasította Szőnyit, hogy az uralkodó halálának alkalmából minden gyülekezet köteles Istentiszteletet tartani.[7]

Ehhez hasonlóan életbevágóan fontos volt, hogy az egyházközségek tisztában legyenek az egyházakra vonatkozó hatályos szabályokkal, mert a Türelmi Rendelet kihirdetése előtt ezen múlhatott egy-egy település nyilvános vallásgyakorlásának joga, de 1781 után is szükséges volt ezek ismerete. Érthető, hogy az egyházlátogatásokon szigorúan ellenőrizték, hogy a gyülekezetben megvannak-e a királyi rendeletek. Évekkel 1781 után is nagyon részletesen írták elö, milyen iratokkal kell minden egyházközségnek rendelkezni: 1787. február elsején Hódmezővásárhelyen tartott egyházmegyei gyülés elhatározta, hogy Csongrád, Csanád és Békés vármegyéktől megkéri a királyi parancsolatok másolatát, amelyeket elküldenek a gyülekezeteknek, és az egyházlátogatás 7. pontjában le fogják ellenőrizni ezek meglétét.[8]

Az egyház vagyonát, intézményeit érintő kérdésekben szintén a gyors információterjesztés igénye figyelhető meg. Az iskolák müködtetése központi kérdés volt a református egyházban, hiszen a Ratio Educationis kiadása óta rendszeresen harcolniuk kellett az állam központosító törekvéseivel szemben (Bucsay Mihály 1985: 165-169.). Nem meglepő, hogy az egyházkerület utasította az egyházmegyéket, hogy az iskolákkal kapcsolatos újabb állami szabályozást minél előbb az egész tractus területén hirdessék ki:

"A Fő Tiszteletü Superintendentianak az Oskolak dolgaban kiküldött Instructiojanak és a V. Tractustol rendeltetett Deputationak arra tett alkalmaztato jegyzéseinek felolvastatasok, és ezeknek a jegyzéseknek helybe hagyások után rendeltetett hogy az az Instructio a jegyzésekkel edgyütt Tiszteletes Senior urunk által az egesz V. Tractusban currentaltassék."[9]

Más esetben a gyors döntéshozatal érdekében a konzisztórium kész volt az előkészített iratokon kívül mást is figyelembe venni. Így például az elbocsátott erdőhegyi prédikátor, Darótzi János esetében nem állt minden dokumentum az egyházi bíróság rendelkezésére, ezért elhatározták, hogy lovast indítanak Aradra az iratok mielőbbi megszerzésének érdekében: 
"Ami pedig a prédikátort peralá fogó szentenziát illeti, minthogy azt a Tractus még nem vehette, kérődjék meg baráttságosan Arad vármegyei főszolgabíró Tek. Stanislovits Úr, mint az említett szententziának proculgátora, hogy azon szentencziát még ide a fenn álló consistoriumra megküldeni méltóztatna."[10]

Ehhez hasonló eset lehetett egy egyházmegyei gyülés is, mert 1821-ben Hevessy Benjámin szentesi városi jegyző egy hivatalost igazolást adott ki arról, miért nem érkezett meg időben a vásárhelyi egyházmegyei gyülésre egy levél:

"Az alól írt napon, és esztendőben, bizonyságot tészek arról, hogy Tekintetes Csongrád Vármegyébe helyheztetett H. M. Vásárhely Mvárossába, f. a. 15a Junii tartatott Fő Tiszteletü Superintendentalis Deputatio által, dél utáni, 2 és 3 óra között, Tisztelendő Juhász István Esperest Úrhoz utasitott levél, egy vásárhelyi czigány aszszony kezébe, Szentesre való által hozás végett adatott, a ki is a nékie által adott levéllel az nap el nem indúlt, hanem 16a Junii indúlt el Vásárhelyről és az nap Szeghvárra jött szállásra, ezt meg tudván a Fő Tiszt Superintend. Deputatio, egy lovas által 16 Juni éjszaka 10 óra tajban tudóstott, hogy ha azon bojgásba lévő levelet veszem azonnal, küldjem Nagy Tiszt Esperest Úrhoz, de mivel a levél még nem érkezett az nap, hanem 17a Junii került reggeli 7 óra tájban kezembe, előbb el nem küldetődhetet, vévén pedig azonnal lovas által el küldöttem, de már azon napon a Fő Tiszt. Superint. Deputatio Vásárhelyről el oszlott."[11]

Az egyházmegye egészét érintő ügyekben általában körleveleket adtak fel, amelyben nem a postai terjesztést választották, hanem a földrajzi távolságok alapján egymáshoz közel eső eklézsiák lelkészeit kérték meg a továbbításra. Ezek az útvonalak általában a Maros-mentén és a Körösök-mentén fekvő településeknek voltak címezve, így biztosították azt, hogy csatárlánchoz hasonlóan egymást értesítsék a gyülekezetek. 1795-ben Szentmiklósi Sebők Sámuel egyértelmủen ezt az utat választotta körlevele továbbítására, amelyre kifejezetten meg is kérte a lelkészeket:

"Kérem szeretettel Kegyelmeteket, hogy az eféle kőzönséges dológban járó currenseket ne sajnáljak mindenüt ujj coperatióban tsinálni, és a magok petséttyek alatt egygyik ekklésiából másikban ugy küldeni elébb."[12]

A források azt mutatják, hogy ezek a nagyobb közönség számára szánt információk valóban eljutottak a címzettekhez. Sajnos nem maradt fenn az összes egykori egyházközség presbiteri jegyzőkönyve, de azt tudjuk, hogy Szentesen külön leirati protokollumba másolták be ezeket a körleveleket, míg Hódmezővásárhelyen a presbitériumi jegyzőkönyvekbe jegyezték be azokat. (SzNREL I.375.b.1-2.; HÓRGyL Presbiteri jegyzőkönyv 1795-1806.)

A következőkben azt nézzük meg, milyen információkat igyekeztek eltitkolni és milyen eszközök álltak erre rendelkezésre. 


\section{Eltitkolt információk}

1790-ben II. József halála után felerősödtek a tiltakozások a központosító politika ellen. A református egyház szempontjából ez kényes helyzet volt, mert az összehívott országgyülés és a koronázási előkészületek feszült helyzetet teremtettek, amelyben a protestánsok érdeke a status quo fenntartása volt (Bucsay Mihály 1985:173-177.). Nem meglepő, hogy a tiszántúli püspök úgy küldött utasítást Szőnyi Benjámin esperesnek, hogy a diéta elé kerülő törvényeket és az országos politikai híreket ne ismertessék a gyülekezetekben. Helyette a háborgókat nyugtassák meg, hogy nem lesznek sorozások és a só ára sem fog emelkedni. A superintendens hangsúlyozottan kérte, hogy ez a levele maradjon titokban:

"Ezt a curre(n)st T. Prédikátor Uraimék tsak magokba tartsák és másoknak ne mutassák, mert az által alkalmatosság szolgaltatodnék balvélekedésekre, és éretlen beszédekre a kösség között, mellyet el kell tavoztatni."[13]

Az általam átnézett források alapján ez a levél nem került illetéktelen kézbe, az viszont más kérdés, hogy az 1790-es évek politikai mozgalmai a vármegyéken keresztül a gyülekezetekbe is beszivárogtak.

A további dokumentumok nem érintenek ilyen országos ügyeket, de a titkolózás, információ-visszatartás sokszor gyors eredményt hozott. Az elhalt makói lelkész, Ecsedi Miklós ügyében a konzisztórium eredetileg úgy határozott, hogy javait írják össze. A végrehajtók viszont túllépték hatáskörüket, mert nemcsak összeírták az ingóságokat, hanem el is árverezték azokat. Annak ellenére, hogy az esperesi utasítást megszegték, tettüket nem ítélték el, hanem tudomásul vették.[14]

Az esperes többször is észrevette, hogy a hozzá eljuttatott iratok nem tükrözik a valóságot, mert a gyülekezetnek nem áll érdekében vele közölni a teljes igazságot. A makói gyülekezet például sokáig megtagadta, hogy az elbocsátott kántor, Újvárosy Mihály ügyében eljutassa a panaszait az espereshez, aki így tehetetlen volt, és nem tudott dönteni az ügyben.[15] Ehhez hasonlóan 1811-ben a torontálvásárhelyi egyházközség bepanaszolta Légárdi Márton tanítót az esperes előtt, mert az bugyuta éneklésével megzavarta az istentiszteletet, de mélyen elhallgatta, hogy a lelkész többször gorombán viselkedett Légárdival. Az ügy végül az egyházkerület elé került, amelyen megfeddték a torontálvásárhelyiek viselkedését. A végzés egyenesen úgy fogalmaz, hogy eltitkolnak valamit a superintendentia előtt: "... eltitkolt okokból hozott ellene sententiát és az által mind magát, mind a superintendentiát, a militáris directioval compromittálta."[16]

1791-ben a tiszántúli egyházkerületben kettős püspökválasztás történt, mert az egyházkormányzatba a lelkészi kar jelentős többsége nem akarta bevonni a világiakat. Sinai Miklós püspök a presbiteri kormányzás korlátozása mellett, Hunyadi Ferenc püspök a 
világiak szerepének erősítése mellett állt ki. A békési egyházmegyében is megfigyelhető volt a megosztottság. A Sinai pártját fogó lelkipásztorok igyekeztek anyagilag is támogatni püspöküket, hiszen az éppen ekkor összehívott zsinaton való részvételét valahogyan finanszírozni kellett. Tudjuk, hogy Sinait kizárták a zsinatról és a superintendensi tisztségről is lemondatták, amellyel a hyerarchikusok harca elbukott (Révész Imre 1959: 178-211.). Ezek alapján nem meglepő, hogy a békési traktusban a lelkészek igyekeztek titokban tartani Sinaihoz füződő viszonyukat, de az információ mégis kiszivárgott, mert Kuthi Ádám assessor egyik levelében arról panaszkodott, miszerint "Hihető hogy valamelly Gyulai Gyülésünkben jelent volt atyafi által tudhatták meg olly hamar a dolognak közöttünk lett folyását..."[17]

A laikusok és az egyháziak közötti ellentétek a későbbi években is megfigyelhetőek voltak, hiszen Domokos Lörinc fögondnok többször is összetüzésbe került az esperessel, amiért az eltitkolt elöle valamit. Ezek közül az egyik elhallgatás egyben megalázó is lehetett Domokos számára, mert ő hivatalból az egyházmegye világi vezetője volt, mégis 1795-ben az esperes nem értesítette arról, hogy közgyülést fognak tartani. Végül a föjegyző küldött egy meghívót, de abban csak követként számítottak Domokos jelenlétére, nem elnökként. [18] Sokáig vita folyt azon is, hogy az egyházkerület körrendeleteit az esperes, vagy a főgondnok kapja-e meg előbb, mert Debrecenből mindenből csak egy példányt küldtek.[19] Az esperes 1800-ban azzal is megpróbálkozott, hogy utólag módosította a konzisztórium határozatait.[20] Természetesen a főgondnok sem hagyta magát megtéveszteni, amely abból látszik, hogy más esetben meg ő nem volt hajlandó egy esperesi körlevelet továbbküldeni. [21] 1795-ben azt is kifogásolta, hogy a közgyülési jegyzőkönyv véglegesített változata nem egyezett a piszkozattal.[22]

Az egyházmegye vezetésének azzal is meg kellett küzdenie, hogy a gyülekezetek egyszerüen eltüntettek iratokat, és nem voltak hajlandóak azokat visszaszolgáltatni. Így például Bereczk Péter hódmezővásárhelyi lelkész egy helyi lakossal összetüzésbe keveredett, és vizsgálatot indítottak ellene. A vásárhelyi presbitérium egyszerüen magához vette a vonatkozó aktákat és azokat nem akarta visszaszolgáltatni, amelyen az esperes felháborodott, és követelte az ügymenet zavartalan folytatását:

"Meg illetődve olvasom Kegyelmetek hozzám utasitott utolsó levelekben mellyet tegnap estve későn vettem, azon magok meg határozását mely szerént azokat az Actakat, mellyeket Vésztőn publica fide et auctoritate a vissza küldésnek igérete alatt a Kegyelmetek Expressussanak által adván, nem akarják vissza küldeni hozzám, hanem magok fogják a Deputationak által adni. De valyon mi okon? Nem de nem én vagyok e dologban a bíró, és így az egész dologról nem Kegyelmetek, hanem énnékem kell az Deputatiot informálnom. Vévén azért ezen levelemet azonnal által küldjék, és tovább magoknál ne tartoztassák."[23] Az egyházmegye alapvető érdeke volt olyan lelkészi kar fenntartása, akik a református 
hitelvek mellett életük végéig kitartanak, erkölcsös életüek és a vallásos élet értékeit hirdetik. Ennek érdekében szükséges volt a lelkipásztorok olvasmányainak ellenőrzése is, amelyet egyházlátogatások során vizsgáltak meg. Több olyan vizitációs utasítást is ismerünk, amelyek hangsúlyozottan felhívják a végrehajtók figyelmét, "hogy visitatio alkalmatosságával tudakozzák meg a prédikátorokat, minémü tudományban találtak hivatalos foglalatosságaik mellett gyönyörüséget, micsoda könyveket olvastak, s miket jegyzettek ki azokból.•(Kis Bálint 1992:156). Úgy tűnik ezek az ellenőrzések nem voltak túl sikeresek. A fentebbi rendelet értelmében 1811-ben az egyházlátogatás kérdései között szerepelt a prédikátor olvasmányaira vonatkozó kérdés, de a gyülekezetek felében azt megválaszolatlanul hagyták, és néhány év múlva teljesen eltünt a vizitációs anyagból ennek számonkérése (TtREL I.29.h.1). Az ellenőrzés lazaságára utal az is, hogy 1796-ban az újonnan beiktatott lelkészek elmondott prédikációinak teljes körü ellenőrzését is elrendelték, amelynek értelmében a lelkipásztorok kötelesek voltak az összes elhangzott igehirdetésüket az esperesnek megküldeni. A gyakorlatban viszont ez csak azt jelentette, hogy a prédikátorok egy jegyzékben tájékoztatták felettesüket a kiválasztott textusokról, és az esperes ezek közül kért be tetszése szerint néhány prédikációt:

"Tőrvény lévén nálunk, hogy az ujj Tiszt. Prédikátorok tartoznak bizonyos okokra nézve 3 elsőbb esztendőbéli munkájokat az Esperestnek be mutatni. Az esperest pedig vagy mindnyája munkájokat esztendőként kezéhez veszi vagy tsak azoknak textusainak serieset, es azokból választ némely kezéhez venni valókat..."[24]

\section{Végkövetkeztetések}

Az esetek ismertetése után nézzük meg, mennyire sikerült az információk nyilvánosságra hozása illetve eltitkolása. Egyben igyekszem megválaszolni azt a kérdést is, hogy az elhallgatás vagy nyilvánosságra való hozás milyen módszerrel történt: az egyházmegye hivatalos csatornáin keresztül, vagy informális úton.

Úgy gondolom, az egyházmegye többnyire el tudta azt érni, hogy a nagyobb érdeklődésre számot tartó híreket, rendeleteket minden gyülekezetben kihirdessék. Az egyházlátogatások során csak a kisebb lélekszámú egyházközségekben jegyezték meg, hogy nem voltak megtalálhatóak a vallási kérdésekkel foglalkozó jogszabályok másolatai. A fentebbiekben bemutatottakból látható, hogy a hatályos jogszabályok gyüjtése és a gyülekezet müködéséhez szükséges információk közzététele olajozottan működött, hiszen például a hatékony és gyors döntések érdekében az egyházmegyei gyülés hajlandó volt ügyrendjét is átalakítani és megvárta a késedelmes iratokat.

Az információk korlátozásának eredményessége már kevésbé értékelhető, mert csak azokról a turpisságokról tudunk, amelyeket a kortársak észrevettek. Ettől függetlenül 
megállapítható, hogy rendszeresen igyekeztek az információkat visszatartani, amely különböző érdekeket szolgáltak. II. Lipót koronázási előkészületeit az egyház igyekezett minél csendesebben átvészelni, miközben a gyülekezetek is titkolóztak az esperesük előtt, ha a személyes konfliktusaik úgy kívánták. Bizonyos esetekben a fögondnokot is igyekeztek kihagyni a döntésekből, hiszen az esperes nem értesítette őt az egyházmegyei közgyülés összehívásáról.

A formális és informális csatornák kérdése a fentebbiekhez képest viszont nehezen megválaszolható, ugyanis az írott források kevés adatot tartalmaznak a szóbeli közlésekkel kapcsolatban, márpedig az informális tájékozódásnak ez alapvető eszköze volt. A bemutatott dokumentumokban a szóbeliség szerepét nem is vizsgáltuk, mert lehetetlen lenne azt rekonstruálni, viszont a súlyát jól mutatja, hogy Úri Sándor gyomai lelkipásztor palástvesztésében jelentős szerepe volt: "... a dolgot rész szerént mellőző, rész szerént egyenesen meg valló írásos és szóbeli (kiemelés tőlem) feleletekből a tetemesebb vád pontokat nagy részént igaznak látta."[25]

Az átnézett iratokból az egyértelmủen megállapítható, hogy a hierarchikus egyházigazgatási rendszerben kialakult formális közlési forma a békési traktusban is létrejött: a püspök utasításokat küldött az esperesnek, amelyeket az esperes juttatott el az egyházközségekhez. Ez a többlépcsős információs hálózat fordítva is müködött, hiszen a gyülekezeteknél felmerült problémákat először az egyházmegye tárgyalta, és csak ezt követően kerültek az egyházkerülethez. Természetesen informális kapcsolatrendszer több ponton is tetten érhető. Ilyennek tekinthetjük az iratok visszatartását, vagy azt az esetet, amikor a Sinait támogató lelkészek szervezkedése meglepő gyorsasággal kiderült.

\section{JEGYZETEK}

[1] A tanulmány az MTA Bolyai János Kutatási Ösztöndíj támogatásával készült.

[2] Másolat Hódmezővásárhely és az egyházkerület között zajló levelezésből, 1787. (TtREL I.29.i.67. nr. 10b)

[3] Például Kis Bálint szentesi lelkész assessori rangban vizitálta a bánáti gyülekezeteket 1816-ban. Debelliátsról, Rittbergről M. Ittebéröl Frantzfeldről visitationalis relatio de a (nno) 816. T. assessor Kis Bálint úr által TtREL I.29.c.15.

[4] Szabadi István igazgató úr szóbeli közlése.

[5] 1812. május 25-én a Hódmezővásárhelyen tartott egyházmegyei közgyülésen megállapították, hogy a levéltár rendkívül rendezetlen, és ezért Kis András esperesre és 
Nagy Ferencre bízták annak rendezését, de ez nem történt meg. (Kis Bálint 1992: 157.) 1818-ban szintén sikertelenül próbálkoztak meg az irattári rend kialakításával.

(Egyházkerületi közgyülés jegyzőkönyvi kivonata, 1818. október 3-5. TtREL I.29.c.16. nr. 58.)

[6] Például Domokos Lőrinc fögondnok 1800. május 27-én írásban beadott egy előterjesztést az egyházmegye közgyülése számára, de maga az irat elkallódott, csak annyit tudunk róla, hogy azt felolvasták a gyülésben. (Egyházmegyei közgyülés, Gyula, 1800. május 27. TtREL I.29.a.2.)

[7] Hunyadi Ferenc levele Szőnyi Benjaminnak, Debrecen, 1792. március 27. (TtREL I.29. c.12.)

[8] "Megkéri a tractualis consistorium Békés, Csongrád, Csanád egyesült vármegyék viceispánját, hogy azon királyi parancsolatokat, melyeket eddig az ideig a helységek bírói által csak extractusba közlöttek, egész párba adja ki." (Kis Bálint 1992: 139.)

[9] Egyházmegyei közgyülés, Makó, 1796. március 15-16. (TtREL I.29.a.2.)

[10] Egyházmegyei közgyülés, Nagyzerénd, 1808. február 10-11. (TtREL I.29.a.2.)

[11] Hevessy Benjámin szentesi városi jegyző nyilatkozata. Szentes, 1821. szeptember 25. (TtREL I.29.i.67. nr. 157.)

[12] Szentmiklósi Sebők Sámuel esperesi körlevele Szentes, 1795. augusztus 8. (TtREL I.29.c.25.)

[13] Szathmári Paksi István körlevele. Debrecen, 1790. május 19. (TtREL I.29.f.3.)

[14] Egyházmegyei közgyülés Békésszentandrás, 1803. június 23. (TtREL I.29.a.2.)

[15] Juhász István esperes levélfogalmazványa a makói egyháznak 1817 körül. (TtREL I.29. c.25.)

[16] Egyházkerületi jegyzőkönyv kivonata, 1811. január 13. (TtREL I.29.c.16. nr. 46.)

[17] Kuthi Ádám assessor körlevele az egyházmegye számára, Öcsöd, 1791. szeptember 14. (TtREL I.29.c.15.)

[18] Domokos Lőrinc levele Szentmiklósi Sebők Sámuelnek, Gyula, 1795. május 4. (TtREL I.29.c.14.) 
Hegyi Ádám: "...A BÉ KÜLDÖTT INFORMATIONAK VÉLÜNK VALÓ NEM KÖ...A BÉKÉSI REFORMÁTUS EGYHÁZMEGYÉBEN A 18-19. SZÁZAD FORDULÓJÁN

[19] Domokos Lőrinc levele Szentmiklósi Sebők Sámuelnek, Gyula, 1793, június 4. (TtREL I.29.c.14.)

[20] Domokos Lőrinc levele Kúthi Ádámnak, Gyula, 1800. augusztus 22. (TtREL I.29.c.14.)

[21] Domokos Lőrinc levele Kuthi Ádámnak, Gyula, 1798. augusztus 1. (TtREL I.29.c.14.)

[22] Domokos Lőrinc levele Kuthi Ádámnak, Gyula, 1795. április 2.(TtREL I.29.c.14.)

[23] Szentmiklósi Sebők Sámuel levele a hódmezővásárhelyi gyülekezetnek, Szentes, 1798. március [?] (HÓRGyL 2. csomó nr. 119.)

[24] Kuthi Ádám leve Vecsei Sámuelnek, Öcsöd, 1803. július 26. (TtREL I.1.b.42.807). Vö.: Egyházmegyei közgyülés, Hódmezővásárhely, 1796. április 22. (TtREL I.29.a.2.)

[25] Egyházmegyei közgyülés kivonata, Gyoma, 1803. szeptember 27. (TtREL I.1. b.42.807.)

\section{FORRÁSOK}

Hódmezővásárhely Ótemplomi Református Gyülekezet Levéltára (HÓRGyL)

HóRGyL 2. csomó: Levelek. 2. csomó 1732-1800.

HÓRGyL Presbiteri jegyzőkönyv 1795-1806: H. M. Vásárhelyi Refor.

Eklésiának Protocolluma 1795dik eszt. 19. Aprilis kezdődvén és tart 1806dik esztendőbéli 23dik Decemebrig.

\section{Szentes Nagytemplomi Református Egyházközség Levéltára (SzNREL)}

SzNREL I.375.b.1-2. Leirati jegyzőkönyv 1786-1859.

\section{Tiszántúli Református Egyházkerület Levéltára (Debrecen) (TtREL)}

TtREL I.1.b.16-67. Püspöki hivatal iratai. Egyházkerületi közgyülési iratok 17791822.

TtREL I.1.b.42.807. Püspöki hivatal iratai. Egyházkerületi közgyülési iratok 1779-1822. Úri Sándor gyomai káplán fegyelmije heterodoxia miatt 1803.

TtREL I.29.a.2. Békés-bánáti egyházmegye iratai. Közgyülési jegyzőkönyv 1787-1829. 
TtREL I.29.f.3. Békés-bánáti egyházmegye iratai. Felsőbbhatósági körlevelek 1606-1948. Püspöktől érkezett körlevelek, levelek 1766-1878.

TtREL I.29.c.12. Békés-bánáti egyházmegye iratai. Esperes által külön kezelt iratok 1691-1979. Elmozdított tanítók, kitiltott tanulók 1794-1905 1-97; egyháztörténet, krónikai feljegyzések 1761-1889 1-36.

TtREL I.29.c.15. Békés-bánáti egyházmegye iratai. Esperes által külön kezelt iratok 1691-1979. Elegyesek (lelkészi naplók) 1820-1916.

TtREL I.29.c.16. Békés-bánáti egyházmegye iratai. Esperes által külön kezelt iratok 1691-1979. Jegyzőkönyvek, kivonatok 1782-1883. Nr. 1-165.

TtREL I.29.c.25. Békés-bánáti egyházmegye iratai. Esperes által külön kezelt iratok 1691-1979. Esperesi körlevelek 1787-1880.

TtREL I.29.h.1. Békés-bánáti egyházmegye iratai. Egyházlátogatási jegyzőkönyvek 1786-1993. Egyházlátogatási iratok 1786-1843.

TtREL I.29.i.67. Békés-bánáti egyházmegye iratai. Egyházközségekre vonatkozó iratok. Hódmezővásárhely 1765-1841.

TtREL I.29.o.1. Békés-bánáti egyházmegye iratai. Igazgatási iratokhoz segédletek 1816-1948. Esperesi napló 1816-1862.

\section{IRODALOM}

Barcsa János (1908): A Tiszántúli Református Egyházkerület történelme. I-III. köt. Debrecen: Faragó György Nyomdája.

Bucsay Mihály (1985): A protestantizmus története Magyarországon 1521 1945. Budapest: Gondolat.

Gaál Endre (2001): A szegedi nyomdászat 1801 - 1918. Szeged: Csongrád Megyei Levéltár.

Glatz Jákob - Márton József (1818): Az ausztriai Tsász. Kir. Birodalomban 1817ben tartatott reformázió öröminnepének elöadása némelly közönséges észrevételekkel együtt, mellyek a protestánsoknak a nevezetes birodalomban lévö egyházi állapotjokat illetik. Németül kiadta Glatz Jákob..., magyar nyelven közrebotsátotta Márton József..., Bétsben: Pichler Antal betüivel.

Kis Bálint (1992): A Békés-Bánáti Református Egyházmegye története. Békéscsaba-Szeged: Csongrád Megyei Levéltár. 
Körmendy Lajos (szerk.) (2009): Levéltári kézikönyv. Budapest: Osiris.

Karvalics László, Z.(2012): Információtörténelem. Aetas 4. 5-12.

Molnár Ambrus (1989): A Tiszántúli református falusi társadalom forrásairól. In. Erdmann Gyula (szerk.): Kutatás, módszertan. Konferencia, Gyula, 1987. augusztus 27-28. Gyula: Békés Megyei Levéltár 328-333.

Molnár Ambrus (1995): A református egyházszervezet és önkormányzat áttekintése, Theológiai Szemle, 38. (5.) 269-274.

Novák Veronika (2007): Hírek, hatalom, társadalom. Budapest: Gondolat. Révész Imre (1959): Sinai Miklós és kora. Budapest: Akadémiai Kiadó.

Révész Kálmán (1860): 1791. évben Budán tartott nemzeti zsinatban hozott egyházi kánonok. Sárospataki Füzetek. 1860. (4.) 58-97.

Révész Kálmán (1891): Emlékkönyv a budai és a pesti zsinatok százados évfordulójára. Budapest: [sine nomine].

Stillson, Richard. T. (2008): Spreading the World: A History of Information in the California Gold Rush. Nebraska: University of Nebraska Press.

Szabó Ferenc (2008): Az Alföld a 18. századtól a 20. század derekáig. In Szabó Ferenc: Két és fél évszázad az Alföld történetéböl. Szeged: Csongrád Megyei Levéltár 82-151.

Szabó Zoltán József (2004): A magyar református egyházszervezet első két évszázada, Budapest: Szenci Molnár Társaság.

Szentpéteri Kun Béla (1948): A magyarországi református egyház külső rendje. Budapest: Magyar Református Egyház.

Szommer Gábor (2004): A Kelet-Indiai Társaság találkozása Japánnal. In Z. Karvalics László - Kiss Károly (szerk.): Információáramlás a kora újkorban. Budapest: Gondolat 162-190.

Tóth Endre (1964): A tiszántúli egyházkerület igazgatásának és az esperesi egyházlátogatásnak rendje 1762-ből. Debrecen: Debreceni Református Theologiai Akadémia.

Weller, Toni (2008): Information History - An Introduction: Exploring an Emergent Field. Oxford: Chandos Publishing.

Weller, Toni (2012): Egy információtörténeti évtized: a szakirodalom és az elméletek áttekintése. Aetas 4. 221-235. 
Zoványi Jenő (2004): A magyarországi protestantizmus története 1895-ig. I-II. kötet. Máriabesenyő - Gödöllő: Attraktor.

A tartalomhoz $>>$ 